\title{
The Effects of Water Intake, Fruits and Vegetables Consumption, and Socio-Cultural on Obesity among Adolescents
}

\author{
Nita Aprilia'), Didik Tantomo'), Pawito3), Bhisma Murti²) \\ 1)Masters Program in Public Health, Universitas Sebelas Maret \\ 2)Faculty of Medicine, Universitas Sebelas Maret \\ 3)Faculty of Social and Political Sciences, Universitas Sebelas Maret
}

\begin{abstract}
Background: The prevalence of obesity is increasing in the world, especially in Indonesia. Obesity can cause health problems, such as hyper-insulinemia, diabetes, cardiovascular disease, hypertension, immunological disorders, certain types of cancer, etc. This study aims to analyze the influence of consumption of water, fruit and vegetables and socio-cultural views on the risk of obesity in senior high school adolescents.

Subjects and method: This was a cross-sectional study conducted at 25 senior high schools in Banyuwangi, East Java, from March to April 2018. Samples of 225 students were selected using random sampling technique. The dependent variable was obesity. The independent variables were consumption of water, fruit and vegetables and socio-cultural views. The data were collected using questionnaires and analyzed using multilevel logistic regression.

Results: Water consumption ( $b=-2.67$; CI 95\% $=-3.77$ to $-1.58 ; \mathrm{p}=<0.001$ ), fruit and vegetables $(\mathrm{b}=-1.16$; CI 95\% $=-1.88$ to $-0.44 ; \mathrm{p}=0.002)$, activity physical $(\mathrm{b}=-1.12 ; 95 \% \mathrm{CI}=-2.08$ to -0.15 ; $\mathrm{p}=0.023)$ and socio-cultural views $(\mathrm{b}=-1.89 ; \mathrm{CI} 95 \%=-2.72$ to $-1.05 ; \mathrm{p}=<0.001)$ reduce risk of obesity . Genetic factors $(b=3.12 ; 95 \% \mathrm{CI}=1.98$ to $4.26 ; \mathrm{p}=<0.001)$ increase the risk of obesity. Senior high school has a contextual effect on the risk of obesity with ICC $=9.89 \%$.

Conclusion: The risk of obesity decreases with adequate consumption of water, consumption of enough fruits and vegetables, enough physical activity and living in a society with a socio-cultural outlook with a good diet. The risk of obesity increases with the presence of factors. SMA has a contextual influence on the risk of obesity in adolescents.
\end{abstract}

Keyword: water, fruit and vegetables, socio-cultural views, obesity

\section{Correspondence:}

Nita Aprilia. Masters Program in Public Health, Universitas Sebelas Maret.Jl. Ir.Sutami No. 36 A, Surakarta, Central Java. Email: nitaapriliamelia@gmail.com. Mobile: +6283847987215.

\section{BACKGROUND}

According to the World Health Organization (WHO, 2016) Overweight and obesity is a state of pathology as a result of consuming excess food from the body's needs so that body weight reaches more than $20 \%$ of normal weight. Obesity is an accumulation of fat in adipose tissue that is abnormal or excessive so that it reaches a level that can cause health problems, such as hyper-insulinemia, diabetes, cardiovascular disease, hypertension, immunological disorders, several types of cancer (Kurdanti et al., 2015). The prevalence of obesity in Indo- nesia is increasing every year in both urban and rural area in which eating habits and physical activity are parts of component of behavior. Both are influenced by environmental, socio-economic, and cultural factors. Socio-cultural factors have a major influence on lifestyle habits or healthy eating patterns. Some groups of people who are obese are teenagers (Dewi et al., 2015).

Obesity has become a serious threat to humanity throughout the world. Adults who are unhealthy have a higher risk of heart disease, cancer, stroke and type 2 diabetes (Arfailasufandi et al., 2016). Affected 
Journal of Health Promotion and Behavior (2018), 3(4): 279-289

https://doi.org/10.26911/thejhpb.2018.03.04.08

adults can die up to 3 to 7 years earlier than those around their age with a healthy weight. In 2013, 42 million infants and small children were overweight or obese. Worldwide, 70 million young people will be overweight or obese by 2025 if current trends continue. The prevalence of obesity in children aged 2-20 years in Indonesia is quite high. According to WHO, the prevalence of obesity in children and adolescents in Indonesia is $18 \%$ in 2016 (WHO, 2017).

Thirteen provinces with obesity prevalence above national standard include East Java, West Java, Aceh, West Papua, North Sumatra, Central Sulawesi, Riau Islands, North Maluku, DKI Jakarta, Bangka Belitung, East Kalimantan, Gorontalo and North Sulawesi (WHO, 2017). Obesity examinations in East Java amounted to $15.48 \%$ or about 2,826,082 residents and those who were obese were $11.16 \%$ or 315,512 people with a proportion of men at $8.07 \%$ (91,323 residents) and women of $13.23 \%$ (224,189 residents). Whereas the prevalence of obesity in Banyuwangi was $89.97 \%$ or 63.6114 people (Jatim Health Office Province, 2016). Obesity occurs because of adequate food, which is accompanied by an imbalance between the intake and output in and out of the body which will cause accumulation of fat deposits in adipose tissue especially subcutaneous tissue (Fairclough et al., 2018).

Fat deposits occur in the abdominal area which causes increased pressure on the diaphragmatic muscles. Excessive accumulation of fat under the diaphragm and inside the chest wall can suppress the lungs. Then breathing problems and shortness of breath arise, even though the sufferer only does mild activity. Respiratory disorders can occur during sleep and cause temporary cessation of breathing, so that during the day the sufferer often feels drowsy (Fairclough et al., 2018).
Obesity can cause a variety of orthopedic problems, including lower back pain and worsening osteoarthritis (especially in the hip, knee and ankle area). Also sometimes skin disorders are often found. Obesity can be caused by many risk factors that directly affect obesity, namely; Complex interactions between family, genetics, environment, community and regional characteristics, culture, and social behavior have produced an energy imbalance (Banwell et al., 2011).

Factors that positively affect obesity include physical activity, skipping meals, and eating high-fat foods, all of which have often been seen in teenage girls in Taiwan. Cultural and ethnic differences in perceptions of weight are the driving factors in the obesity epidemic. Some countries and cultures consider a person's body size to be larger and an unhealthy lifestyle as a sign of health and status (Banwell et al., 2011). For example, in Latino culture, overweight children are considered a sign of wealth and parents' wealth, so weight gain is considered positive (Banwell et al., 2011).

The prevalence of obesity increases immigrants who live longer in the United States. This has been observed in Latin Americans and Hispanics born in the United States, as they are twice as likely to be obese as their counterparts born elsewhere or have recently immigrated. This is evidence that ethnic differences are strongly influenced by environmental factors (Banwell et al., 2011).

According to the Indonesian Society of Obesity Study, the handling of obesity is carried out based on five principles, namely: motivation, diet regulation, healthy lifestyle, medical therapy and surgery. Motivation is an effort to improve individual health knowledge at least regarding the management of disease risk factors and clean and healthy lifestyle in an effort to improve the 
health status of participants, prevent reemergence of diseases and restore disease (Yensel et al., 2011). To maintain the quality of life and avoid the impact of obesity, everyone must live a healthy lifestyle, which is eating balanced foods such as fruit and vegetables, drinking water, and regular exercise (Andini et al., 2016).

The nutrients needed in adolescence include protein, minerals, zinc, iron, vitamins and fiber. In addition to fulfilling macro nutrients, micronutrients for adolescents are also needed, especially fiber and vitamin intake (Febriani et al., 2017). Much of the evidence that shows an increase in consumption of dietary fats and sugars is the tendency to eat food away from home. The low consumption of vegetables and fruit is associated with an increased risk of chronic diseases as a long-term impact of obesity (Kurdanti et al., 2015).

The authors were interested in conducting a study under the issue of "The Effect of Water, Fruit and Vegetable Consumption and Socio-Cultural Views on the Risk of Obesity in Senior High School Adolescents in Banyuwangi Regency, East Java"

\begin{tabular}{l}
\hline SUBJECTS AND METHOD \\
\hline 1. Study Design \\
This was a cross-sectional study conducted \\
at 25 high schools in Banyuwangi, East \\
Java, from March to April 2018.
\end{tabular}

\section{Population and Sample}

The study population was all senior high school teenagers in Banyuwangi. A sample of 225 students was selected using the random sampling technique.

\section{Study Variables}

The dependent variable was obesity. The independent variables were consumption of water, fruit and vegetables and socio-cultural views.

4. Operational Definition of Variables

Water consumption was defined as original water without being mixed with anything that is colorless and odorless. The ideal water consumption behavior of adolescents is 2 liters.

Consumption of fruit and vegetables was defined as a balanced diet menu. Adolescent behavior of consuming enough fruits and vegetables is 3 times a day.

Socio-cultural views were defined as all things created by humans with their thoughts and thoughts of conscience for and / or in social life. It also means adolescents who live in communities with a socio-cultural outlook with a good diet.

Genetics were defined as hormones or genes that are passed on to children. It can be said as teenagers who have obese family members.

Physical activity was defined as workout or sports or activities carried out every day. It is the behavior of teenagers doing physical activity every day.

Obesity was defined as body weight reaching more than $20 \%$ of normal weight. The normal juvenile BMI is $18-24 \mathrm{~kg} / \mathrm{m} 2$.

\section{Study Instruments}

The instruments in the study were questionnaires, weight scales and height meters. Questionnaires were tested by validity and reliability tests.

\section{Data Analysis}

Univariate analysis was performed to see the frequency distribution and characteristics of the study subjects. Bivariate analysis was performed using Chi-Square and the calculation of Odds Ratio (OR) with 95\% Confidence Interval (CI) to study the relationship between the risk of obesity and the independent variable. Multivariate analysis was performed using a multilevel model multiple logistic regression test as indicated by the Intra-Class Correlation (ICC) value run at Stata 13.

\section{Research Ethics}

Research ethics include informed consent, 
Journal of Health Promotion and Behavior (2018), 3(4): 279-289

https://doi.org/10.26911/thejhpb.2018.03.04.08

anonymity, confidentiality, and ethical approval. It has obtained ethical permission from the Health Ethics Research Ethics Commission, Faculty of Medicine, Sebelas Maret University, Surakarta, Central Java, No.49 / KEPK / 2019.

\begin{tabular}{l} 
RESULTS \\
\hline 1. Univariate Analysis \\
General description of study data includes \\
consumption of water, fruit and vegetables, \\
as well as socio-cultural views, physical \\
activity, genetics and obesity.
\end{tabular}

Table 1. Univariate analysis

\begin{tabular}{lcc}
\hline Variable & n & \% \\
\hline Gender & & 60.9 \\
Female & 137 & 39.1 \\
Male & 88 & 59.6 \\
Water Consumption & 134 & 40.4 \\
Lacking & 91 & 51.6 \\
Enough & & 48.4 \\
Fruits and vegetables consumption & 116 & \\
Adequate & 109 & 58.7 \\
Socio cultural perspective & & 41.3 \\
Poor & 132 & 60 \\
Good & 93 & 40 \\
Genetic & & \\
Nes & 135 & 16.9 \\
Physical Activities & 90 & 83.1 \\
Adequate & & \\
Low & 38 & 58.2 \\
Obesity & 187 & 41.8 \\
\hline Normal & & \\
\hline
\end{tabular}

Table 1 showed that of the 225 study samples that consumed enough water, there were $40.6 \%$ and $59.6 \%$ consumed less water. Study samples that consumed enough fruits and vegetables were $48.6 \%$ and $51.6 \%$ consumed less fruits and vegetables. In terms of good socio-cultural views, $41.3 \%$ and $58.7 \%$ are bad sociocultural views of lifestyle. The study sample assessed no genetic history in the family of 48.6\% and as many as $51.6 \%$ had a genetic history. The sample of the study which assessed physical activity was less than 83.1\% and $16.9 \%$ did good physical activity. The study sample which was measured in height and weight experienced overweight / obesity as much as $58.2 \%$ and as much as 41.8\% in normal BMI conditions.

\section{Bivariate Analysis}

Table 2showed the effect of independent variables (consumption of water, fruit and vegetables and socio-cultural views, physical and genetic activities) to the dependent variable (overweight / obesity). 
Aprilia et al./ The Effects of Water Intake, Fruits and Vegetables Consumption

Table 2. Bivariate analysis

\begin{tabular}{|c|c|c|c|c|c|c|c|c|}
\hline \multirow{3}{*}{ Independent Variable } & \multicolumn{4}{|c|}{ Obesity } & \multirow{2}{*}{\multicolumn{2}{|c|}{ Total }} & \multirow{3}{*}{ OR } & \multirow{3}{*}{$\mathbf{p}$} \\
\hline & \multicolumn{2}{|c|}{ Yes } & \multicolumn{2}{|c|}{ No } & & & & \\
\hline & $\mathbf{n}$ & $\%$ & $\mathbf{n}$ & $\%$ & $\mathrm{n}$ & $\%$ & & \\
\hline Water Consumption & & & & & & & & \\
\hline Inadequate & 65 & 48.5 & 69 & 51.5 & 134 & 100 & 0.36 & $<0.001$ \\
\hline Adequate & 66 & 72.5 & 25 & 27.5 & 91 & 100 & & \\
\hline Fruit and vegetable & & & & & & & & \\
\hline consumption & 54 & 46.6 & 62 & 53.4 & 116 & 100 & 0.36 & $<0.001$ \\
\hline Inadequate & 77 & 70.6 & 32 & 29.4 & 109 & 100 & & \\
\hline Adequate & & & & & & & & \\
\hline Socio-cultural perspective & 62 & 47 & 70 & 53 & 132 & 100 & 0.31 & $<0.001$ \\
\hline Poor & 69 & 74.2 & 131 & 25.8 & 93 & 100 & & \\
\hline Good & & & & & & & & \\
\hline Genetic & 92 & 68.1 & 43 & 31.9 & 135 & 100 & 2.80 & $<0.001$ \\
\hline Yes & 39 & $43 \cdot 3$ & 51 & 56.7 & 90 & 100 & & \\
\hline No & & & & & & & & \\
\hline Physical Activity & 13 & 34.2 & 25 & 65.8 & 38 & 100 & 0.30 & 0.001 \\
\hline Good & 118 & 63.1 & 69 & 36.9 & 187 & 100 & & \\
\hline Poor & & & & & & & & \\
\hline
\end{tabular}

There was a relationship between consumption of water and the risk of adolescents being obese. Teenagers who consume enough water have a risk of obesity $1 / 3$ smaller compared to those who consume less water $(\mathrm{OR}=0.36 ; \mathrm{p}<0.001)$.

There was a relationship between fruit and vegetable consumption and the risk of adolescents being obese. Adolescents who consume enough fruits and vegetables have a risk of obesity $1 / 3$ smaller compared to those who consume less water $(\mathrm{OR}=0.36$; $\mathrm{p}$ $<0.001)$.

There was a relationship between sociocultural views and the risk of adolescents being obese. Adolescents who live in communities with socio-cultural patterns with good diet have a risk of obesity $1 / 3$ times compared to those who live in communities with poor diet $(\mathrm{OR}=0.31 ; \mathrm{p}<0.001)$.

There was a relationship between the family's genetic history and the risk of adolescents being obese. Teenagers who have a family genetic history have a risk of obesity 2.80 times compared to those without a genetic history $(\mathrm{OR}=2.80 ; \mathrm{p}<0.001)$.

There was a relationship between physical activity and the risk of adolescents being obese. Teenagers who have enough physical activity have a risk of obesity $1 / 3$ compared to those who lack physical activity $(\mathrm{OR}=0.30 ; \mathrm{p}=0.001)$.

\section{Multivariate Analysis}

The results of data processing using multilevel multiple logistic regression analysis obtained the following results (Table 4). 
Journal of Health Promotion and Behavior (2018), 3(4): 279-289

https://doi.org/10.26911/thejhpb.2018.03.04.08

Table 4. Multiple multilevel logistic regression analysis

\begin{tabular}{|c|c|c|c|c|}
\hline \multirow{2}{*}{ Variable } & \multirow{2}{*}{$\mathbf{b}$} & \multicolumn{2}{|c|}{$\begin{array}{l}\text { CI } 95 \% \\
\end{array}$} & \multirow[b]{2}{*}{$\mathbf{p}$} \\
\hline & & Lower Limit & Upper Limit & \\
\hline \multicolumn{5}{|l|}{ Fixed Effect } \\
\hline Water consumption & -2.67 & -3.77 & -1.58 & $<0.001$ \\
\hline Fruit and vegetable consumption & -1.16 & -1.88 & -0.44 & 0.002 \\
\hline Socio-cultural perspective & -1.89 & -2.72 & -1.05 & $<0.001$ \\
\hline Physical Activity & -1.12 & -2.08 & -0.15 & 0.023 \\
\hline Genetic & 3.12 & 1.98 & 4.26 & $<0.001$ \\
\hline \multicolumn{5}{|l|}{ Random Effect } \\
\hline Constanta & 0.36 & 0.04 & 3.01 & \\
\hline \multicolumn{5}{|l|}{$\mathrm{N}$ observation $=225$} \\
\hline \multicolumn{5}{|l|}{$\mathrm{N}$ school $=25$} \\
\hline \multicolumn{5}{|l|}{ Average $n$ per school $=9$} \\
\hline \multicolumn{5}{|c|}{ Likelihood random $=-102.01$} \\
\hline \multicolumn{5}{|c|}{ LR test vs. Logistic regression, $\mathrm{p}=0.008$} \\
\hline $\mathrm{ICC}=9.89 \%$ & & & & \\
\hline
\end{tabular}

Table 3 showed the results of a multilevel multiple logistic regression. There was a relationship between consumption of water and the risk of obesity in adolescents. Adolescents who consumed enough water had logodd for obesity 2.67 units lower than those who consumed less water $(b=-2.67$; CI 95\% $=-3.77$ to $-1.58 ; \mathrm{p}<0.001)$.

There was a relationship between fruit and vegetable consumption and the risk of obesity in adolescents. Adolescents who consumed enough fruits and vegetables had logodd for obesity 1.16 units lower than those who ate less fruits and vegetables $(b=-$ $1.16 ; 95 \% \mathrm{CI}=-1.88$ to $-0.44 ; \mathrm{p}=0.002$ ).

There was a relationship between sociocultural views and the risk of obesity in adolescents. Adolescents who live in communities with a socio-cultural pattern with good diet have logodd of experiencing obesity 1.89 units lower than those living in a poor diet $(b=-1.89$; CI 95\% $=-2.72$ to -1.05 ; $\mathrm{p}<0.001)$.

There was a relationship between physical activity and the risk of obesity in adolescents. Adolescents with sufficient physical activity had logodd for obesity 1.12 units lower than those who lacked physical activity $(b=-1.12 ; 95 \% \mathrm{CI}=-2.08$ to $-0.15 ; \mathrm{p}$ $=0.023$ ).
There was a relationship between the family's genetic history and the risk of obesity in adolescents. Adolescents with a family genetic history had logodd for obesity 3.12 units higher than those without a genetic history $(b=3.12$; CI $95 \%=1.98$ to 4.26 ; $\mathrm{p}<0.001)$.

There was an effect random high school contextual factor on the variation of multiple logistic regression $(b=0.36 ; 95 \%$ $\mathrm{CI}=0.04$ to 3.01 ).

LR test vs. Logistic regression produces $\mathrm{p}$ 0.008. This means that the multilevel multiple logistic regression analysis models shows a statistically significant difference with the usual logistic regression model. ICC $=9.89 \%$ means that $9.89 \%$ of the variation in obesity was determined at the contextual level of high school.

\section{DISCUSSION}

\section{Effect of water consumption on the risk of obesity in adolescents}

The results of the analysis show that there was a relationship between consumption of water and the risk of obesity in adolescents. Adolescents who consumed enough water had logodd for obesity 2.67 units lower than those who consumed less water $(\mathrm{b}=-$ 2.67; CI 95\%=-3.77 to $-1.58 ; \mathrm{p}<0.001)$. The 
results are in line with the study by Lakoro et al. (2016) regarding the pattern of consumption of water, milk and milk products, and sweet drinks as a risk factor for obesity in elementary school children who were obese as much as $67.2 \%$. Showing differrences in consumption of less water with OR 2.1 (95\% CI; 1.4 to 3.05; $\mathrm{p}=0.003$ ).

In California, the promotion of water consumption in children is proposed to replace the consumption of sweet drinks, because sweet drinks are suspected to be the cause of obesity in children. Giving water to children is arranged in such a way as not to interfere with the intake of other foods that contain essential nutrients for child growth and development (Lakoro et al., 2016). Study in Germany for one school year found results that administration of water accompanied by education of the benefits of water can reduce the risk of obesity by $31 \%$ (Lakoro et al., 2016).

Similarly, other studies also found that the addition of water consumption of $10 \mathrm{~mL} / \mathrm{kg}$ body weight in obese children could increase (REE) up to $25 \%$. In this study, it was found that REE was significantly associated with the child's age, height, weight, and body fat mass (Lakoro et al., 2016). This program aims to change the behavior of consumption of sweet drinks and unhealthy foods for children by encouraging children to bring supplies in the form of water and fruits in their lunch (Lakoro et al., 2016). After 2 years, the program was evaluated and it turned out that it succeeded in changing the consumption behavior of children with an increase of $15-60 \%$ of children bringing water to school and reducing 8-38\% of the habit of bringing sweet drinks, and 25-50\% of children carrying fresh fruit in stock lunch (Lakoro et al., 2016).

Mulyasari et al. (2017) study asserts that consuming 30 minutes of water before eating as much as $454 \mathrm{ml}$ for five weeks can reduce the body's fat in girls who experience over nutrition.

\section{The effect of fruit and vegetable consumption on the risk of obesity in adolescents}

The results of the analysis have a relationship between fruit and vegetable consumption and the risk of obesity in adolescents. Adolescents who consumed enough fruits and vegetables had logodds for obesity 1.16 units lower than those who ate less fruits and vegetables $(b=-1.16 ; 95 \% \mathrm{CI}=-1.88$ to -0.44; $\mathrm{p}=0.002)$. In line with the study of Widianto et al. (2017) about adolescent nutrition obtained an analysis of the relationship between efficacy and consumption of vegetables and fruits obtained that as many as 71 (93.4\%) adolescents with efficacy that lacked the amount of consumption of vegetables and fruits is less. Adolescents in the category of efficacy are good, with 32 (40\%) good consumption of vegetables. The statistical test results obtained that there is a significant relationship between efficiency and consumption of vegetables and fruit.

The results of the analysis obtained $\mathrm{OR}=9.47$, meaning that teens who have good self-efficacy have a chance of 9.47 times to consume vegetables and fruits compared to adolescents who have less efficacy. The relationship between efficacy and consumption of vegetables and fruit can be used as the basis for interventions to increase vegetables and fruits in adolescents.

Dewi et al. (2015) explained that adolescents do not consume enough fruit and vegetable portions every day. They often consume fast food with a limited menu and them like high calories, high fat and sodium food. This causes overweight and obesity. Fruits and vegetables are a source of fiber that teenagers must consume because they are still in the development phase. 
Journal of Health Promotion and Behavior (2018), 3(4): 279-289

https://doi.org/10.26911/thejhpb.2018.03.04.08

Adolescents who are obese provide more fruit and vegetables than those who have normal weight. Fruit consumption is very good for obese people because the fruit has high fiber. Fibrous foods are very well consumed in quantities that suit your needs. Dietary fiber actually has an important function that cannot be replaced by other substances which can help prevent constipation, prevent hemorrhoids, lose weight and prevent degenerative diseases such as coronary heart disease, hypertension, diabetes mellitus, hypercholesterolemia, colon cancer and stroke (Febriani et al., 2017).

Vegetables can prevent the occurrence of obesity because it can reduce hunger but does not cause excess fat, cholesterol, and so on. Vegetables generally also contain crude fiber which can help facilitate digestion and prevent constipation. Many children do not like vegetables in the food menu for reasons because it tastes less tasty. Certain family eating patterns that do not prioritize vegetables in the main food menu add to the severe lack of vegetable intake in children (Yuliah et al., 2019).

\section{Effect of socio-cultural views on the risk of obesity in adolescents}

The results of the analysis have a relationship between socio-cultural views and the risk of obesity in adolescents. Adolescents who live in communities with a socio-cultural pattern with good diet have a logodds of experiencing obesity 1.89 units lower than those who live in a poor diet $(\mathrm{b}=-1.89$; CI $95 \%=-2.72$ to $-1.05 ; \mathrm{p}<0.001)$.

Lestari et al. (2016) stated that there was a significant difference $(p<0.050)$ saturated fat intake before and after giving peer nutrition counseling. Peer nutrition counseling has an effect on decreasing the intake of saturated fats in adolescents. In European and Asian countries, especially in Indonesia itself, the most common parenting style in society is the upbringing of democracy. This is different from the parenting style adopted by the countries of Australia and the United States which more often uses authoritarian parenting in caring for their children. It can be concluded that cultural or cultural differences can cause differences in the types of parenting used by parents in caring for their children (Banwell et al., 2011).

This is what can distinguish the differences in the results of study on parenting parents with a tendency to overweight in children varies in each country. Although so far no one has been able to explain in detail how parenting can increase the risk of trends in obesity in children (Banwell et al., 2011).

Socio-culture is the same as child care in the culture of the surrounding community. Democratic parenting is a form of parenting that encourages children to be free but still limits and controls their actions. Parents who apply this upbringing have prioritized children's interests compared to their own interests but they are not reluctant to control children. Authoritarian parenting is characterized by parents who tend to set standards that must be obeyed by children, usually along with threats (Banwell et al., 2011).

Parents tend to force, rule and punish. The pattern of permissive parenting is the opposite of the pattern of authoritarian parenting. Everything is centered on the interests of the child. Parenting is generally characterized by parents giving children the opportunity to do something without sufficient supervision. Parents do not control behavior according to the child's personality development needs (Banwell et al., 2011).

4. Effect of physical activity on the risk of obesity in high school adolescents

The results of the analysis have a relation- 
ship between physical activity and the risk of obesity in adolescents. Adolescents with sufficient physical activity had logodds for obesity 1.12 units lower than those who lacked physical activity $(\mathrm{b}=-1.12 ; 95 \% \mathrm{CI}=$ -2.08 to $-0.15 ; \mathrm{p}=0.023)$. In line with the study of Wijayanti et al. (2019) that physical activity has a negative relationship to obesity in children. Children with high physical activity reduced the risk of high fat and obesity with results $(\mathrm{b}=-0.04 ; 95 \% \mathrm{CI}$ $=-0.05$ to $-0.06 ; \mathrm{p}<0.001)$.

According to Niswah et al. (2017) it was mentioned that physical activity has a direct negative effect on overweight in adolescents. Adolescents who engage in physical activity have less potential to be overweight (high $\mathrm{BMI}$ ) than results $(\mathrm{b}=0.05 ; \mathrm{SE}=$ $0.001 ; p=0.002)$. The benefits of physical activity for adolescents include maintaining healthy muscles and joints, improving mood, reducing anxiety, stress, depression, improving sleep quality, reducing the risk of heart disease, stroke, high blood pressure, and diabetes, improving blood circulation, improving the functioning of vital organs such as the heart and lungs lung, and reduce the risk of cancer due to being overweight (Niswah et al., 2017).

\section{Genetic influence on the risk of obesity in high school adolescents}

The results of the analysis show that there was a relationship between family genetic history and the risk of obesity in adolescents. Adolescents with a family genetic history had logodds for obesity 3.12 units higher than those without a genetic history (b = 3.12; CI 95\% = 1.98 to 4.26; $p<0.001$ ). This result is in line with the study of Andini et al. (2016) which states that obese family members influence the incidence of obesity. If parents of children are not obese or overweight, the possibility of obesity genes can be obtained from grandparents because obesity can be reduced.

\section{The effect of high school strata on the risk of obesity in high school adolescents}

The results of the analysis contained effect random high school contextual factors on the variation of the multiple logistic regression constants $(b=0.36 ; 95 \% \mathrm{CI}=0.04$ to 3.01). LR test vs. Logistic regression produces $\mathrm{p}$ 0.008. This means that the multilevel multiple logistic regression analysis model shows a statistically significant difference with the usual logistic regression model. ICC $=9.89 \%$ means that $9.89 \%$ of the variation in obesity is determined at the contextual level of high school.

\section{AUTHOR CONTRIBUTION}

Nita Aprilia, the main researcher, played a role in collecting and processing research data. Didik Tamtomo examined the conceptual framework and research methodology. Pawito reviewed the research paper.

\section{FUNDING AND SPONSORSHIP}

This study used independent costs by the main researcher.

\section{ACKNOWLEDGEMENT}

My appreciation goes to the heads of high schools in Banyuwangi who have helped with the study and students who participate and are willing to become study respondents.

\section{CONFLICT OF INTEREST}

There is no conflict of interest in this study.

\section{REFERENCE}

Andini AR, Septadina IS (2016). Pengaruh faktor keturunan dan gaya hidup terhadap obesitas pada murid SD Swasta di Kecamatan Ilir Timur 1 Palembang cepat saji. 6 Makanan cepat saji merupakan case control dan dilakukan pada dua sekolah berat badan (BB) yang diukur dengan timbangan Has. Jurnal 
Journal of Health Promotion and Behavior (2018), 3(4): 279-289

https://doi.org/10.26911/thejhpb.2018.03.04.08

Kedokteran Kesehatan. 3(2): 114-119.

Arfailasufandi R, Mudigdo A, Sudiyanto $A(2016)$. The effect of obesity, oral contraceptive and passive smoking on the risk of cervical cancer. Jounal of Epidemiology and Public Health. 4(3): 189-197.

Banwell C, Kinmonth H, Dixon J (2011). The social, cultural and familial contexts contributing to childhood obesity. 6: 127-138. https://doi.org/10.1016/B9780123749956.10012-X.

Dewi E, Angkasa L, Pamungkasari EP, Dharmawan R (2015). Effects of fruit and vegetable consumption, a socioeconomic factor of adolescent obesity in Surakarta City.Journal of Health Promotion and Behavior. 2(1): 55-64.

Fairclough SJ, Dumuid D, Mackintosh KA, Stone G, Dagger R, Stratton G, Boddy LM (2018). Adiposity, fitness, healthrelated quality of life and the reallocation of time between children's school day activity behaviours: A compositional data analysis.11(4): 254261. https://doi.org/10.1016/j.pmedr.2018.07.011.

Febriani RT, Soesetidjo A, Tiyas FW (2017). Consumption of fat, protein, and carbohydrate among adolescent with overweight/obesity. Journal of Maternal and Child Health. 4(2): 70-76.

Jawa Timur Health Office Province (2016). Accessed from www.depkes.go.id/resources/download/profil/PROFIL_K ES.../15_Jatim_2016.pdf

Kurdanti W, Suryani I, Syamsiatun NH, Siwi LP, Adityanti MM, Mustikaningsih D, Sholihah KI (2015). Faktorfaktor yang mempengaruhi kejadian obesitas pada remaja. Jurnal Gizi Klinik Indonesia. 11(04): 179-190.

Lakoro Y, Hadi H, Julia M (2016). Pola konsumsi air, susu dan produk susu, serta minuman manis sebagai faktor risiko obesitas pada anak sekolah dasar di Kota Yogyakarta dan Kabupaten Bantul. Jurnal Gizi Dan Dietetik Indonesia (Indonesian Journal of Nutrition and Dietetics), 1(2): 102-109. https://doi.org/10.21927/ijnd.2013.1(2).102-109.

Lestari E, Dieny FF (2016). Pengaruh konseling gizi sebaya terhadap asupan serat dan lemak jenuh pada remaja obesitas di Semarang. Journal of Nutrition College. 5(1): 36-43.

Mulyasari I, Muis SF, Kartini A (2017). Pengaruh asupan air putih terhadap berat badan, indeks massa tubuh, dan persen lemak tubuh pada remaja putri yang mengalami gizi lebih. Jurnal Gizi Indonesia, 3(2), 120-125. https://doi.org/10.14710/jgi.3.2.120-125.

Niswah SR, Soemanto RB, Murti B. (2017). Factors associated with overweight and obesity in adolescents in Kartasura, Central Java. Journal of Health Promotion and Behavior. 2(3): 207217.

Widianto F, Mulyono S, Fitriyani P (2017). Remaja bisa mencegah gizi lebih dengan meningkatkan self-efficacy dan konsumsi sayur-buah. Indonesian Journal of Nursing Practices, 1(2): 16-22. https://doi.org/10.18196/ijnp.1257 .

Wijayanti D, Salimo H, Lanti Y, Dewi R (2019). Multilevel Analysis on the Determinants of overweight and obesity among primary school students in Boyolali, Central Java. Journal of Maternal and Child Health. 4(5): 304-311.

World Health Organization (2016). Obesity. Accessed from https://www.who.int/topics/obesity/en/

World Health Organization (2017). Accessed from http://apps.who.int/gho/data/view.main.BMIPLUS1Co5-19v?lang=en. 
Aprilia et al./ The Effects of Water Intake, Fruits and Vegetables Consumption

Yensel C, Tolman C (2011). Nursing perspective on childhood obesity. Chapter 6: 57-69. https://doi.org/10.1016/B978-0-12-374995-6.10006-4.

Yuliah Y, Adam A, Hasyim M (2019). Kon- sumsi sayur dan buah dengan kejadian obesitas pada remaja di SMA Negeri 1 Mamuju. Jurnal Kesehatan Manarang, 3(1): 50. https://doi.org/10.33490/jkm.v3i1.35. 